\title{
Shaping conditions for entrepreneurship in climate change adaptation: a case study of an emerging governance arrangement in the Netherlands
}

\author{
Debora de Block ${ }^{l}$, Peter H. Feindt ${ }^{2,3}$ and Erik van Slobbe ${ }^{1}$
}

\begin{abstract}
Planning and implementation of regional climate change adaptation requires new, integrated governance arrangements that often involve public and private actors. Although entrepreneurship is widely considered an important part of such arrangements, little is known about the conditions that enable it, and its actual role is under-researched. Through an in-depth case study of an ecosystem-based adaptation project in the Netherlands, we have analyzed how the variegated actors in a governance network shape six conditions for entrepreneurial success, established in the entrepreneurship literature. Through a framing analysis, we found that all six conditions, i.e., prior career experience, altruistic motivations, financial motives, social networks, financial capital availability, and policies and regulations, were the object of constant negotiations. Their salience varied during the project as a result of variegated framing practices. In the early stages, issue, identity, and relationship frames were used to create a network of people with a range of relevant experience, connected by altruistic motivations. However, as the project progressed, distrust frames and different spatial- and temporal-scale frames created tensions between public and private actors. Accordingly, process frames, financial motivations, and capital availability became increasingly salient, reflecting the need to consolidate rules, roles, and responsibilities. The findings suggest that approaches to climate change adaptation imply ongoing struggles over the conditions that enable entrepreneurial success. We thereby add an important new dimension to the study of adaptation governance.
\end{abstract}

Key Words: climate change; ecosystem-based adaptation; entrepreneurship; governance arrangements

\section{INTRODUCTION}

Adaptation to climate change is a quickly emerging field of policy, practice, and research. Concerns often surface around the resilience of infrastructures and land use patterns, with a focus on technical and material measures (Feindt and Netherwood 2011, Bulkeley and Castán Broto 2013). Recent scholarly discussions, however, increasingly focus on the potential of ecosystem services to enhance resilience to climate change (Jones et al. 2012, Bourne et al. 2016). Ecosystem-based adaptation (EbA) uses biodiversity and ecosystem services to help people adapt to climate change and includes the conservation, restoration, and even creation of ecosystems (Brink et al. 2016). Examples of EbA are flood regulation through sustainable water management and securing future food provision through conserving diverse agricultural landscapes (Secretariat of the Convention on Biological Diversity 2009).

The existing literature on EbA generally stresses the contribution of the approach to the supporting, provisioning, regulating, and cultural services that ecosystems provide. Hence, the benefits of EbA beyond climate change adaptation are often emphasized, e.g., in terms of contributions to biodiversity, livelihoods, and human health (Milman and Jagannathan 2017). However, the processes through which $\mathrm{EbA}$ provides these benefits are often complex and insufficiently understood. This includes uncertainty about the effect of climate change on an ecosystem's ability to continue to provide its services into the future. Also, the time needed for the adaptation benefits to arise may not always coincide with the time when costs are felt (Jones et al. 2012). From a governance perspective, this raises questions about suitable mechanisms to improve the likelihood of timely, effective, and efficient EbA measures.
Research suggests that the governance of climate change adaptation requires new roles for both public and private actors so that responsibilities are shared and necessary resources mobilized (Mazmanian et al. 2013, Dewulf et al. 2015, Huitema et al. 2016). The study of public-private partnerships, understood as "collaboration between actors from the different spheres of society" (Van Huijstee et al. 2007:76) has yielded relevant knowledge on the functioning of these new forms of partnerships and on success factors (Van Huijstee et al. 2007). However, the governance of climate change adaptation requires additional attention because it needs to consider long time horizons and the associated uncertainties (e.g., Mees et al. 2012, Tompkins and Eakin 2012, Swart et al. 2014).

In this context, we are interested in the contribution of entrepreneurship to EbA, i.e., the capacity to innovate and take risks to develop and exploit opportunities for the creation of new ecosystem services, markets for these services, and actor constellations that maintain these services. We are interested in how both public and private entrepreneurs shape conditions for success in the context of uncertainties related to climate change. Although some scholars argue that entrepreneurship is a promising avenue to contribute to climate change adaptation and biodiversity conservation (e.g., Dean and McMullen 2007, Lambooy and Levashova 2011), the conditions that entrepreneurs need to contribute to EbA and the processes through which conditions for successful entrepreneurship in EbA are developed, negotiated, and shaped remain unclear. The overall aim of our research is therefore to better understand how conditions for entrepreneurial success in adaptation projects are shaped over time through the interactions of public and private actors. For this, we follow a case study approach (Yin 2003). Our main

${ }^{1}$ Water Systems and Global Change Group, Wageningen University and Research, ${ }^{2}$ Albrecht Daniel Thaer Institute for Agricultural and Horticultural Sciences, Humboldt University at Berlin, ${ }^{3}$ Strategic Communication, Wageningen University 
question is: How do public and private actors negotiate the conditions for entrepreneurship during an EbA project?

\section{CONCEPTUAL FRAMEWORK}

\section{Conditions for entrepreneurship in ecosystem-based adaptation}

Business and management research (e.g., Shane 2003, Fuentes Fuentes et al. 2010) has identified various conditions for successful entrepreneurship. We focus on six of these conditions because these are most mentioned in the literature on $\mathrm{EbA}$ (Doswald and Osti 2011, Naumann et al. 2011). The first three are attributes of the entrepreneur, and the last three are conditions in the entrepreneur's environment. (1) "Prior career experience" $\mathrm{s}$ stems from individual involvement in setting up a business, in marketing, management, product development, and team formation, as well as from vicarious experience gleaned from others such as family, friends, and colleagues (Shane 2003). Entrepreneurs' motivations can be divided into two types: altruistic and financial. (2) "Altruistic motivation" refers to "the individual motivation to improve the welfare of another person" (Penner et al. 2005:368) or, especially relevant for EbA, empathy for animals and their related environmental conditions (Patzelt and Shepherd 2011). (3) "Financial motives" refer to the possibility of increasing an actor's personal or company's economic gains (Dean and McMullen 2007). (4) "Social networks" are useful to garner resources, e.g., knowledge, information, and finances, and to form alliances for joint production of goods and services (Fuentes Fuentes et al. 2010). (5) "Financial capital availability" in the context of EbA stems from subsidies and grants (Halme and Korpela 2014), an actor's own financial resources (Shane 2003), or revenues obtained from products or services (Osterwalder et al. 2010). (6) "Policies and regulations" either facilitate or restrain the introduction of new goods, services, and markets through varying degrees and types of interventions (Dimov 2007).

\section{Governance arrangements}

The conditions for successful entrepreneurship are shaped by governance arrangements, i.e., patterns of interaction constituted through formal and informal rules and roles, for example, the allocation of insiders and outsiders and the distribution of entitlements and obligations (Andersson and Ostrom 2008). For entrepreneurial $\mathrm{EbA}$ projects, these include in particular environmental and planning regulations as the context for arrangements between entrepreneurs and public actors, which might involve financial support, planning permits, or particular project requirements. Such arrangements arise out of processes of negotiation, struggle, and compromise. The characteristics of specific governance arrangements may encourage or discourage actors with particular motivations. In this sense, they connect societal goals and values, in particular the provision of ecosystem services, with individual motives and worldviews, in our case altruistic and financial motivations and career experience.

\section{Analysis approach}

In EbA projects, often neither the problems nor the relevant actor constellations nor the appropriate processes are standardized (Eisenack and Stecker 2012, Adger et al. 2013). This implies that the contextual conditions for entrepreneurial success and the relevant motivations and experiences are likely to be constantly negotiated as well. Although this is a plausible expectation, there is little research on how such processes are unfolding during adaptation projects. In the Methods section, we explain how we deploy a framing approach to analyze the ongoing negotiations in an EbA project and how they involve the conditions for entrepreneurial success.

Analyzing conditions for successful entrepreneurship, as described previously, suggests a positivist approach to studying relations between variables. However, we do not regard conditions for success as "being out there," ready to be exploited, but rather as the emerging outcome of a process in which actors continuously negotiate and shape understandings and conditions for success, a process that we conceptualize as framing (Entman 1993). To guide the analysis of our case, we use the mentioned six conditions as sensitizing concepts, which, instead of providing prescriptions of what to see, merely suggest directions in which to look (Blumer 1954). Although framing approaches have been used to better understand climate change adaptation policies and practices (e.g., Dewulf 2013, Vink et al. 2013, Massey et al. 2015), no study has focused on the framing of the conditions for successful entrepreneurship in adaptation.

\section{METHODS}

\section{Case selection}

On the basis of our research aim, we derived five criteria for case selection: (1) entrepreneurship is at the core of the case; (2) both public and private actors are involved; (3) significant negotiation processes occur within the project; (4) the project is at least in its implementation phase to allow study of developments over time; and (5) access to actors, documents, and interactions is possible. The inland shore Wieringermeer project, in which public authorities together with entrepreneurs collaborated to develop climate adaptive water management in combination with new economic functions, met all the criteria and was therefore considered well suited for an in-depth study. The low-lying Wieringermeer polder north of Amsterdam is vulnerable to floods and droughts, and the socioeconomic structure of the region is highly dependent on agriculture. With freshwater availability and food production predictably affected by climate change more widely, we expect this case to provide lessons for other regions where similar new governance arrangements in climate change adaptation are negotiated.

\section{Data collection}

We used a multimethods approach for collecting data and analyzing the various frames and conditions throughout the project. Access to the field was secured when the main researcher was invited by a project member to join the core project team in mid-2014. She was assigned the role of a reflective observer, providing detailed minutes of the project meetings as a means to administer and monitor the process. In three sessions, she shared her observations and discussed preliminary findings, i.e., identification of frames and conditions for success, as feedback to the project team. These occasions were used as a means to validate the research results. There was no intention to influence the project proceedings. Data were collected until June 2016. Although the project did not end at that point in time, limited time and financial resources made further involvement impossible. The available data allow us to analyze the negotiation of conditions over an extended period of time, and the researchers stayed informed about the latest developments, providing important contextual knowledge. 
The following data were included in the analysis:

- Project documents and communications, including interim project reports, research plans, minutes, and e-mail communication, approved for research use by project participants, from October 2014 to June 2016.

- Participant observation reports: Throughout the project, the main researcher used a reflective diary with preliminary observations and interpretations. These covered 17 meetings of the core project team, 5 networking events, and 3 meetings for informing the general public.

- Semistructured interviews with 5 key project participants representing the main organizations involved, i.e., national and regional government (2), companies (2), and consultancies (1).

\section{Framing analysis}

Framing denotes the process through which people construct and represent their interpretations of the world and communicate about it (Gray 2002). To frame is to "select some aspects of a perceived reality and make them more salient in a communicating context, in such a way as to promote a particular problem definition, causal interpretation, moral evaluation, and/or treatment recommendation for the item described" (Entman 1993:52). Consequently, frames simultaneously direct attention toward some aspects of a situation and away from others. In the Wieringermeer case, we monitored how participants framed issues, identities, relationships, and the process itself.

In issue framing, people use frames to establish the existence and characteristics of a problem (Gray 2002). Issue frames define and limit problem definitions, including their causes and suitable solutions (Lems et al. 2013). An important dimension of issue framing in environmental governance is scale framing (van Lieshout et al. 2011). Following Cash et al. (2006), we define scales as the spatial, e.g., region; temporal, e.g., annual; and jurisdictional, e.g., municipal level, dimensions that are used to describe a phenomenon.

Identity and relationship frames define social positions resulting from and as part of social interactions. Through interactions, individuals claim an identity that is either accepted or contested by others (Dewulf et al. 2009). Identities of social groups are often constructed through comparison with or in opposition to the identity of other groups. During such framing processes, people typically externalize responsibility for negative events to others with contrasting identities (Gray 2002). A specific type of relational frame is the trust frame, which expresses levels of reliability in relationships (de Vries et al. 2014).

Process frames refer to actors' interpretations of actual or desirable forms of interaction. Process framing is dynamic because participants continuously have to make sense of their ongoing interactions through cueing and reacting to each other. Hence, process frames typically shift over the course of an interaction. For example, if one party perceives an EbA project as a bottom-up partnership and the other as an investor-led experiment, then the two parties must negotiate, either consciously or unconsciously, the nature of their process as framed through their continuing interactions (Dewulf et al. 2009).
We inductively identified the issue, identity and relationship, and process frames used in formal meeting minutes, supported by the coding program ATLAS.ti. The analysis focused on frames that addressed or affected the abovementioned conditions for successful entrepreneurship and was guided by the following questions: (1) What issues, identities, relationships, and process frames were used in discussions? (2) Who were the frame promoters? (3) Was the frame accepted or contested, and how? Four decisive events (Teisman 2000) were identified through changes in the frames used and because they were seen as momentous by participants. This suggested a periodization of the project in four distinct stages. We then assessed the frames and discussions on conditions during each stage. In a third step, we triangulated these findings with our own participant observations and e-mail communication. In a fourth step, we used the semistructured interviews to extract interview quotes to make the identified frames explicit, cross-check for any additional frames, and reflect on the negotiated conditions for entrepreneurial success in each stage.

\section{CASE BACKGROUND}

The inland shore Wieringermeer is located along Lake IJssel in the province of North Holland, the Netherlands (Fig. 1). Lake IJssel is one of the largest freshwater lakes in Europe. Different water levels, which are fixed both in summer and winter, are maintained for flood control and to cater to riparian land and water uses like agriculture, urban areas, and recreation. The Wieringermeer polder, in which the inland shore is located, was reclaimed from the lake at the end of the 1920s and serves mainly as an agricultural area.

Fig. 1. Map of the Netherlands with the Wieringermeer encircled.

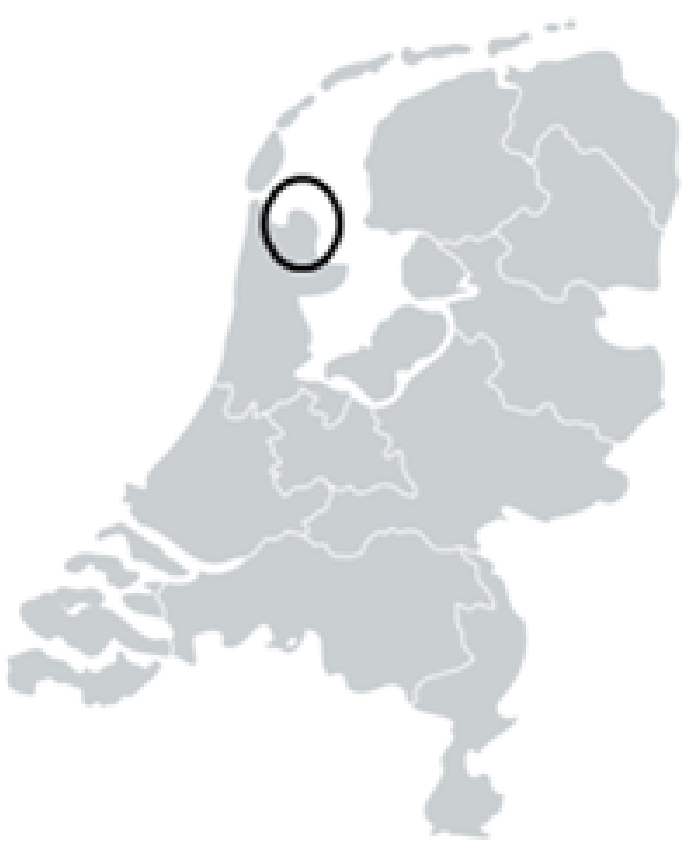

In 2007, the Dutch Cabinet appointed the "Delta Committee" with the task to formulate recommendations for Dutch water management under climate change (Veerman 2008). Regarding 
Lake IJssel, the committee recommended managing the water levels more flexibly to anticipate the effects of climate change and to create larger freshwater storage in summer. This would have significant consequences for lakeshore designs (Deltacommissie 2014). Consequently, local water managers started to develop strategies to adapt riparian land and water uses, including the design of lakeshores. Representatives of the Ministry of Infrastructure and the Environment and a knowledge institute, Deltares, proposed the creation of novel ecosystems named "inland shores," i.e., areas behind the flood defenses where water can be temporarily stored. Such temporary lake water retention would reduce pressure on lake dikes in other locations when water levels are extremely high. The ecosystem services provided by the inland shore areas are therefore temporary overflow storage of water in times of excess, like a natural floodplain, together with, for instance, nature conservation or space for innovative aquaculture such as mitten crab (Eriocheir sinensis) cultivation. Mitten crabs need large water basins, which can also be used for temporary overflow water storage. In 2012, the Koopmanspolder was designated as a 16-ha experimental inland shore to assess the effects of changing water levels on ecology and fisheries. The results were positively evaluated, and consequently, possibilities were explored to create a second, larger scale inland shore in the Wieringermeer.

Entrepreneurship was expected to play an important role in the process because novel combinations of ecosystem services, i.e., the physical design of a large-scale inland shore, as well as new actor constellations involving public and private actors, were to be created. At a more abstract level, harnessing novel provisioning ecosystem services was expected to generate revenues that could contribute to the viability of a project that would also generate regulating ecosystem services. Next, we describe the development process of the project that followed.

\section{RESULTS}

We present an analysis of the unfolding framing of conditions for entrepreneurship during the case. For each of the four stages of the project, we describe the specific framing activities, with particular attention to the conditions for entrepreneurial success that dominated in discussions during each stage.

\section{Stage I: determining the boundaries of the project}

The success of the Koopmanspolder pilot project (see the Case background section) inspired one of its initiators, a civil servant in the Ministry of Infrastructure and the Environment, together with two entrepreneurs to instigate a larger inland shore project in the Wieringermeer polder. A local landowner offered to lease an entire farm of 20 ha to start a project in June 2014. A project team was assembled, initially with people previously involved in the Koopmanspolder project but complementing this "core" team with consultants and civil servants from the municipality and the province of Noord-Holland. During stage I, which lasted 7 months, the actors negotiated the purpose and scope of the project.

\section{Framing in stage I}

During the first months, the rationale behind the project was expressed in terms of ecological pressure and economic opportunity:

$$
\text { The future of the water in the Netherlands: rising sea }
$$
levels, saltier, dryer and wetter [...]. The trends towards
2100 are less freshwater availability and food problems in the world and Europe. In the Netherlands we actually have more than enough freshwater and we are good in agri, so we have to start innovating on better use of freshwater and other types of agri [...] to compete with China, the USA and other parties. (Civil servant, interview statement based on presentation slides, 26 June 2014)

In this quote, the project initiator framed the need for an inland shore project as an economic opportunity that could result from adaptation to climate change. The strong Dutch position in agriculture and water management and the need to innovate in a competitive global economy were linked to articulate a comprehensive frame: It includes an issue frame, i.e., long-term adaptation need, and an identity frame, i.e., the Netherlands as competitor of other global economic powers. It served initially as a motivator to involve the required actors. The inland shore was presented as the local implementation of an essentially national policy that followed, for instance, from the national Delta Program. A communication expert explained: "The idea is to take the story around the Delta Program as a basis and zoom in from this large perspective" (based on minutes, 5 November 2014).

Initially, the core team envisaged two project goals: (1) to create added value for the economy, ecology, and/ or livability using the freshwater from Lake IJssel; and (2) to contribute to water safety (Ministerie van Infrastructuur en Milieu 2015). However, the ecological and nature development aspects were soon questioned by the province and municipality. Their concerns were expressed by the landscape architects involved:

Nature in this polder is as "strange" as buildings, because the polder consists of agricultural land. Also when you focus on fish there is a high chance that the inhabitants and politicians denote it as "nature." Fish and water are seen as withdrawal of fertile agricultural land. (Landscape architects, based on minutes, 3 December 2014)

Consequently, the core team agreed to place "ecology" or "nature" more in the background when communicating about the project. The second objective was "multilayer safety," a specific water management policy. Water managers argued that inland shores would enhance water safety because of their capacity to store water during heavy rains, a reasoning that formed the main justification to involve the Ministry of Infrastructure and the Environment. However, the actual contribution to water safety was soon questioned within the core team with the effect that the contribution of inland shores to water safety was reframed:

An inland shore at this specific location does not contribute greatly to water safety [...], but the concept can be tested at this location after which it can be applied in other parts of the Netherlands. (Landscape architects, based on minutes, 3 December 2014)

Differences in issue frames were linked to divergent understandings of the project scale. The Koopmanspolder initiator originally presented a grand scheme of an approximately $25-\mathrm{km}$ coastline. This motivated the entrepreneurs whose ambition was to develop large-scale new business: "Our final goal is to create $1000-2000$ ha with a number of cultivations" (Entrepreneur, interview, 14 June 2016). However, this large-scale development was contested by the province and the municipality 
because of concerns about potential local opposition. Previous ambitious development projects in the area had failed, and local inhabitants were opposed to more large-scale changes in land use. From December 2014 onward, the project was therefore explicitly framed as a local-scale experiment, with a potential future expansion to regional scale. The entrepreneurs disagreed with this scale reframing, and relations between them and the core team became tense. However, both groups framed their mutual relationship positively: "We know what we can expect from each other [...] and agreed that together we would bring this to a good end" (Entrepreneur, interview, 14 June 2016). "There are different interests [...] but we said: we are going for a higher goal [...]. It is a small team of people that can trust each other blindly" (Civil servant, interview, 26 June 2014).

\section{Conditions of entrepreneurial success in stage I}

The defining and redefining of the project's objectives and scale reflect the attempts to forge a social network of project initiators and supporters and to make the first steps in the creation of a governance arrangement. All actors were attracted to the idea to innovate and offered relevant career experience. The network roughly consisted of three groups. The "water managers" brought experience with the Koopmanspolder pilot and were associated with the Ministry of Infrastructure and the Environment, the water board, and Deltares. Their view on the project was shaped by the perceived need to adapt national water systems to climate change. The "entrepreneurs" were newcomers to Wieringermeer but saw opportunities in EbA. They called for large-scale developments to create financially viable business opportunities. The local authorities, i.e., the municipality and the province, wanted socioeconomic development for their territory but opposed large-scale interventions in the area. This constellation of interests meant that in practice, only the economic motives behind the project were actively addressed by the entrepreneurs, whereas the altruistic motivations, i.e., ecological and nature development aspects, were deliberately placed in the background.

Stage II: expansion of the social network and increased attention to financial issues

The period from January 2015 to April 2015 was characterized by both growing tensions and increasing cooperation between the core team and some of the entrepreneurs. Four entrepreneurial initiatives, focusing on mitten crabs, salt tolerant crops, floating agriculture, and recreational fishing, were now involved in the project. A funding proposal was submitted to the European Fund for Regional Development (EFRO) in April 2015. The proposal outlined the collaborative plans for each cultivation, including upscaling.

\section{Framing in stage II}

In stage II, the upscaling discussion continued, and two entrepreneurs, those exporting mitten crabs and producing salt tolerant crops, decided to contract a formal representative with a network in the local government. They also initiated the legal establishment of a foundation, called AKWA (the Dutch abbreviation for "inland shore cultivation in and on water"), in January 2015. The main task of the entrepreneurs' representative was to establish a covenant between the entrepreneurs. The other parties and the entrepreneurs explicitly saw the initiation of AKWA as an attempt at relationship framing: "There were so many contact persons and so many meetings at the farm. We said: we have to do something to form a block and establish a clear structure" (Entrepreneur, interview, 13 June 2016). However, the core team initially framed the establishment of AKWA as a disruption of the process:

The establishment of AKWA took a lot of time and
energy [...]. This line went straight through our own
structure [...]. Ultimately, things became sharper, but it
also made the process very difficult. (Civil servant,
interview, 14 May 2016)

The other actors also understood the hiring of the representative as an expression of distrust. The core team discussed the trust issue and decided that an agreement would clarify roles and responsibilities of all project participants. Identity and relationship frames were explicitly articulated: "There is a 'we' versus 'them' feeling, but we agree that it should become an 'us' feeling, so together with the entrepreneurs" (Consultants and civil servant, based on observations, meeting, 11 February 2015). Despite these tensions, both the core team and the entrepreneurs continued to frame their relationship as mutual interdependence:

As an entrepreneur I will never be able to realize such an end design. I am not able to construct dikes, to create multilayer safety, that is not my business. So if we can profit from these developments, then of course that is good for us. (Entrepreneur, interview, 13 June 2016)

Considerable time and effort were spent in stage II to acquire additional capital from the EFRO. The proposal writing included a collaborative process frame, bringing the core team and the entrepreneurs closer together again. A consultant coordinated and facilitated the process:

If we had a question, then he answered immediately [...]. He was a bit the cement between the stones, he kneaded it a little [...]. You trust that person, he is helping you again and again. Such a person is very important. (Entrepreneur, interview, 13 June 2016).

Hence, trust was re-emphasized in relationship framing. Also, the core team members acknowledged the crucial role of the consultant in the process. Writing the proposal also reframed the process: "The modus within the project changed, it became more focussed" (Civil servant, based on minutes, 18 March 2015).

Conditions of entrepreneurial success in stage II

Financial motives were expressed through the request of the entrepreneurs to establish a covenant, including statements about intellectual property, governmental commitment, and future upscaling. The social network condition was renegotiated through the addition of the AKWA foundation. The associated reframing of the process also affected the relationships and hence the network condition. The efforts to obtain an EFRO subsidy explicitly addressed the capital availability condition.

Stage III: prevailing process frames based on career experience and financial motives

The plans as defined in the EFRO proposal formed the basis for experiments with mitten crab production and floating agriculture in the spring and summer of 2015.

Framing in stage III

The floating agriculture experiments using Lake IJssel freshwater failed, obviously because the water lacked nutrients. However, the experiment with the mitten crabs turned out successful: "From 
the 1st of May until we measured the crabs, we actually did quite well. [...] I was very proud of the good results, even though everyone said that it was impossible" (Entrepreneur, interview, 13 June 2016). The entrepreneur presented a strong identity and relationship frame of himself as someone who pushed through when others were in doubt. Nevertheless, members of the core team were also pleased with the results: "The economic argument for the inland shores got an enormous boost because the crabs moulted" (Province representative, based on interview, 20 May 2016).

A commonly held opinion was that the successful experiment contributed to maintaining the project's momentum. The entrepreneur immediately revived the discussion about upscaling. However, the governmental parties remained reluctant to speed up the process:

The tension between upscaling or not is a very important threshold where you notice that the government, and also the province, is not really used yet to work together in a project with entrepreneurs. We are saying: first come with results, and then we'll discuss it further. (Province representative, based on interview, 20 May 2016)

Submitting the EFRO proposal together improved the relationship between entrepreneurs and the core team. However, the improved relationship did not endure as the AKWA foundation and the role of the entrepreneurs' representative continued to create tensions: "With AKWA, an additional consultation platform emerges that can lead to noise in the communication. I do not think it is good for the relations within the project" (Representative of Deltares, based on minutes, 27 May 2015). A representative of the water board voiced concern: "Was AKWA started from a strategic point of view? Or is there a lack of trust towards commitment of the governmental parties?" (based on minutes, 27 May 2015). The establishment of AKWA was interpreted as an attempt to frame relationships in terms of distrust between the entrepreneurs and the local authorities. The entrepreneurs, however, framed AKWA as a vehicle to keep the covenant on the agenda.

During this stage, the core team regularly convened after each meeting for a short reflection on the latest developments. The relationship with the entrepreneurs and the process were recurring concerns:

Certain things have indeed gone too slow, especially the governance structure and arrangement of finances, and therefore we are busy putting out fires. Sometimes things indeed go too quick, but from our perspective things also go too slow. (Consultant, based on minutes, 2 September 2015)

Conditions of entrepreneurial success in stage III

The entrepreneurs' continuing call for upscaling and governmental commitment was candidly based on reference to their earlier business credentials, i.e., career experience, and their wish to develop a profitable business, i.e., financial motives, which required economies of scale. The controversy about the scale of operation caused continuous tensions, making the social network condition a continuous object of negotiation. Altruistic motivations, enabling policies and regulations, and capital availability, apart from waiting for the results of the EFRO subsidy, were not explicitly addressed during this stage.

\section{Stage IV: subsidy and European regulation}

Stage IV started when the EFRO subsidy was granted in February 2016. The success reignited the commitment and enthusiasm from the various parties involved. However, soon afterward the project participants learned that the European Union (EU) had included the mitten crab on its draft list of invasive alien species, which would disallow their propagation. This threat to the viability of the mitten crab experiment led to fundamental uncertainty about the continuation of the project and to practically complete cessation of all activities on the farm.

\section{Framing in stage $I V$}

The inclusion of the mitten crab on the list of invasive alien species implied that catching them was still allowed, but farming prohibited. The entrepreneurs, their representative, and the public authorities were caught by surprise and started to lobby the Ministry of Economic Affairs and the EU. The momentum gained after the successful mitten crab experiment and the subsidy grant seemed to vanish because of uncertainty about the publication date of the list and the subsequent implications: "You see that advantage now converting into a disadvantage, it's floating away because the acceleration is gone. I wouldn't be surprised if we would lose a whole year now" (Province representative, interview, 20 May 2016).

Not all project participants framed the process as stalled. The entrepreneurs believed either that there were still possibilities to grow mitten crabs in a controlled environment or that they should continue the planned activities and address the consequences later:

Everyone has a mind-set that says: we want to have the permits first! [...] At the moment when the crabs are there and you start farming, that process will come. Then you go to the European Court and you win [...]. You just have to execute. And the regulation adapts itself. (Entrepreneur, interview, 14 June 2016).

Another possibility was that the EFRO budget for growing the mitten crabs would be withdrawn. Although the participants held different process frames, these were hardly discussed. Instead, lobbying for removal of the crabs from the definitive list was given priority by all parties.

Parallel to the lobbying activities, upscaling discussions between the entrepreneurs and governmental parties continued. Because this issue had been on the agenda from the beginning of the project, reaching a decision became critical for the entrepreneurs. The province questioned the necessity for an upscaling decision because of the uncertainty about the mitten crab production: "You see that a number of parties [...] think: yes, talking about upscaling is very nice, but is it still realistic? You see [...] retreating movements" (Province representative, interview, 20 May 2016). The hesitation of the province was also informed by the realization that upscaling the farming activities would imply major challenges to landscape design:

If you do this, then you cannot just put 400 ha of ponds next to each other, but you have to start talking about 
integration and reaching a number of other goals. Then you also have to look: how does it fit the landscape, does it have a water storage function? And can you connect it with recreation? (Province representative, interview, 20 May 2016)

The differences in spatial-scale frames and process frames were not bridged. Although both parties understood each other's position, the dispute reflected underlying differences in modes of operation, which were also expressed in diverging process frames: Although AKWA called their coveted agreement with the governmental parties a covenant, the province used the term "timetable":

A timetable means that we write down which steps need to be taken to come to upscaling and what is needed for this [...]. At this very moment none of the parties would sign a covenant which says: if the experiments works, we will scale up. That is still a step too far. The entrepreneurs keep calling it a covenant, we call it a timetable [...]. A covenant sounds like you are having an obligation and that is not realistic at this moment. (Province representative, interview, 20 May 2016)

When reflecting on the process, project participants were fully aware that the process frames diverged with regard to speed and modes of operation, both between and within the different parties involved:

\begin{abstract}
You see that different parties - governmental parties, entrepreneurs and knowledge institutes - have different speeds and different ambitions. That can sometimes very much accelerate or delay the process [...]. And: the same bosses that told me: "Great, an innovation project!" can be the people that say: "It should all be accountant proof." Those are two different factors. (Civil servant, interview, 14 May 2016)
\end{abstract}

From the beginning of 2016, the governance structure of the project changed. Partially in response to requirements of the EFRO subsidy, the roles and responsibilities of the different project partners became more defined and legally binding:

You really see that we reach a new phase. The project becomes mature. Roles are distributed differently, you get specializations and the pioneer phase is over [...]. It becomes more professional [...] with all the bureaucracy and efficiency that belongs to it [...]. Now we go from a pioneering role into an evaluation role. (Province representative, interview, 20 May 2016)

Conditions of entrepreneurial success in stage IV

The dynamics in this stage show a clash of different conditions of entrepreneurial success, which are reflected in the frame contests discussed previously. First, impending EU regulations seemed to disallow further extension of the mitten crab production, which impeded the progress of the entire project. Second, the local authorities were unwilling to unconditionally support upscaling of the production activities because this would involve major policy and political investments and because of the uncertainties about the EU regulation. Third, the entrepreneurs did not want to continue at the small, unprofitable experimental scale and emphasized the importance of a covenant. Joint lobbying at the national and European levels increased the cooperation within the social network. The financial motives were not thematized but implicit in the lobbying against the classification of the mitten crab as an invasive alien species. Neither capital availability nor altruistic motives were prominently addressed, the former because the EFRO subsidy was acquired, and the latter because instrumental considerations of project viability dominated the agenda.

\section{DISCUSSION}

First, our results show that the six selected conditions for entrepreneurial success are useful as sensitizing concepts to analyze changing modes of interaction and emerging governance arrangements in EbA projects. The framing analysis showed that each condition was actively addressed at some stage of the project, albeit with varying intensity over time. Consecutive stages of the project also differed markedly in the conditions that players attempted to shape. Struggles about financial motives and social network formation continued throughout all four stages of the project, whereas discussions on capital availability, career experience, altruistic motives, and policies and regulations each emerged in one stage only. Capital availability was eventually achieved by obtaining a subsidy. Arguments on prior career experience were used in the upscaling discussion. Altruistic motivations were deliberately placed in the background in anticipation of sensitivities related to nature development in the area. The discussion on policies and regulations only started during the last stage of our research when the impending implementation of a new regulation threatened the viability of the entire project. The findings suggest that conditions for entrepreneurial success are not static or externally given but coproduced through processes of negotiation, agreement, or contestation between the different players.

Second, our findings confirm the presence of ongoing and probably unavoidable tensions between public and private actors. In our case, these were often expressed through contested spatialand temporal-scale frames, as distrust frames (cf. Swart et al. 2014), and through efforts to reshape relationships. The different scale frames were related to different modes of operation of the three actor groups involved: civil servants from the ministry and researchers focused on Lake IJssel and related water retention for safety and freshwater provision for the next 100 years; the province and municipality officials intended to allow the activities on the 20-ha farm as a protected experimental niche for a period of 10 years but objected to large-scale transformation of agricultural land; and the entrepreneurs saw the project as a first step toward a larger scale business, i.e., 1000-2000 ha, within a short period of time, i.e., a few years. These differences in the positions of public and private actors affect the conditions for effective publicprivate or intersectoral partnerships more generally, in particular, the difficulty in scoping the issue at hand, choosing appropriate goals, and identifying key stakeholders (Van Huijstee et al. 2007:84).

Third, the frame contestation (Dewulf 2013) as observed in our research can be related to two general characteristics of EbA that cause additional difficulties on top of those typical for any publicprivate partnership: the interlinkages between public and private goods and incompatible time frames. Because EbA is supposed 
to provide public goods and services, it can be difficult to convince private actors to invest (cf. Tompkins and Eakin 2012). Ecosystem services addressed in the Wieringermeer case were food production, water supply (both provisioning), and water regulation (regulating). Contested frames could often be traced back to financial motives that required either marketable products or public support, and consequently, many efforts went into acquiring public funding. Furthermore, entrepreneurs conceded that the project was too small to significantly contribute to water regulation and the provision of water for agriculture, but they saw crab farming and saline agriculture as positive contributions to EbA if the project could be upscaled. These frames superseded a focus on regulating ecosystem services and the public-good component with a focus on provisioning ecosystem services and the private-good component. In addition, the timescales of costs and benefits might mismatch because the time needed for the benefits to arise may not always coincide with the time when costs are felt (Jones et al. 2012). The benefits from EbA often require a longer time frame to unfold than for traditional infrastructure ("hard") adaptation measures. EbA might therefore need longer term definitions of returns to investment to appear beneficial (Ojea 2015).

Fourth, the division of labor between public and private parties in our case departs from the liberal model of entrepreneurship. The assumption that public actors establish the enabling conditions for innovations, in particular facilitating policies and regulations, while private actors develop the actual innovation, does not hold for the Wieringermeer case. The novel idea to create an inland shore was introduced by a civil servant who was also strongly involved in the elaboration and actual implementation of the project. This resonates with earlier observations on blurring tasks and responsibilities in public-private partnerships (Van Huijstee et al. 2007).

Finally, our findings demonstrate how framing processes connect the different motivations of variegated groups of actors whose collaboration is needed for EbA projects to succeed. In our case, water managers, civil servants affiliated with various local authorities, and entrepreneurs had to pool their different yet complementary motives, career experiences, and social networks. Their different modes of operation had to be bridged through suitable issue, identity, and relationship frames. This might explain the decreased emphasis on altruistic motives and a shared national identity frame during the early stages of the project. At later stages, however, diverging interests, e.g., regarding the scale of the project, had to be reconciled through precise and reliable arrangements under hard financial and legal constraints, hence the increasing salience of process frames, financial motivations, and capital availability. The emerging governance arrangement remained fluid during the 2-year period of observation, an unsettled state that was reinforced by contested process frames.

\section{CONCLUSION}

We aimed to understand how a set of conditions proven to be generally conducive for entrepreneurial success in climate change adaptation are shaped over time through the interactions of public and private actors. Taking a case study approach, we analyzed the issue, identity, relationship, and process frames that emerged during an EbA project in the Netherlands as a lens to understand the sometimes cooperative, sometimes contested construction of the conditions for entrepreneurial success. Our findings suggest that future research on the factors for successful climate change adaptation should incorporate a dynamic perspective that addresses the processes of co-construction of the various enabling conditions for EbA entrepreneurship. This would permit a more detailed understanding of how decision makers at various policy levels can influence the conditions for entrepreneurial success. Our results further show the importance of the temporal dimension when analyzing EbA initiatives. Various layers of the governance arrangement need to be conducive to entrepreneurial activity at the same time or in the right sequence. Aligning the temporal-scale frames of public and private actors to deal with the public-good nature of EbA is a particular challenge. The finding that the importance of process frames increased as this EbA initiative progressed also has clear practical implications. Projects will be well advised to deliberately take the time to reflect on the diverging and converging framing attempts of their network players. For policy making, this implies that providing space for deliberative and creative processes to align different frames could be an essential part of governance arrangements that increase the likelihood that adaptation projects succeed and that steps are taken to decrease the vulnerability of socialecological systems to climate change.

Responses to this article can be read online at: http://www.ecologyandsociety.org/issues/responses. $\mathrm{php} / 10310$

\section{Acknowledgments:}

The authors would like to thank the initiator of the inland shore Wieringermeer for the opportunity to become closely involved in the project, as well as all other persons involved in the project for their cooperation and valuable comments. This research project was financially supported by Climate-KIC (Knowledge and Innovation Community).

\section{LITERATURE CITED}

Adger, W. N., T. Quinn, I. Lorenzoni, C. Murphy, and J. Sweeney. 2013. Changing social contracts in climate-change adaptation. Nature Climate Change 3(4):330-333. http://dx.doi.org/10.1038/ nclimate 1751

Andersson, K. P., and E. Ostrom. 2008. Analyzing decentralized resource regimes from a polycentric perspective. Policy Sciences 41(1):71-93. http://dx.doi.org/10.1007/s11077-007-9055-6

Blumer, H. 1954. What is wrong with social theory? American Sociological Review 19(1):3-10. http://dx.doi.org/10.2307/2088165

Bourne, A., S. Holness, P. Holden, S. Scorgie, C. I. Donatti, and G. Midgley. 2016. A socio-ecological approach for identifying and contextualising spatial ecosystem-based adaptation priorities at the sub-national level. PLOS ONE 11(5):e0155235. http://dx.doi. org/10.1371/journal.pone.0155235

Brink, E., T. Aalders, D. Ádám, R. Feller, Y. Henselek, A. Hoffmann, K. Ibe, A. Matthey-Doret, M. Meyer, N. L. Negrut, A.-L. Rau, B. Riewerts, L. von Schuckmann, S. Törnros, H. von 
Wehrden, D. J. Abson, and C. Wamsler. 2016. Cascades of green: a review of ecosystem-based adaptation in urban areas. Global Environmental Change 36:111-123. http://dx.doi.org/10.1016/j. gloenvcha.2015.11.003

Bulkeley, H., and V. Castán Broto. 2013. Government by experiment? Global cities and the governing of climate change. Transactions of the Institute of British Geographers 38(3):361-375. http://dx.doi.org/10.1111/j.1475-5661.2012.00535.x

Cash, D. W., W. Adger, F. Berkes, P. Garden, L. Lebel, P. Olsson, L. Pritchard, and O. Young. 2006. Scale and cross-scale dynamics: governance and information in a multilevel world. Ecology and Society 11(2):8. http://dx.doi.org/10.5751/ES-01759-110208

Dean, T. J., and J. S. McMullen. 2007. Toward a theory of sustainable entrepreneurship: reducing environmental degradation through entrepreneurial action. Journal of Business Venturing 22 (1):50-76. http://dx.doi.org/10.1016/j.jbusvent.2005.09.003

Deltacommissie. 2014. Deltabeslissing IJsselmeergebied. Ministry of Infrastructure and the Environment and Ministry of Economic Affairs, The Hague, The Netherlands.

de Vries, J. R., R. Beunen, N. Aarts, A. M. Lokhorst, and R. van Ark. 2014. The pivot points in planning: how the use of contracts influences trust dynamics and vice versa. Planning Theory 13 (3):304-323. http://dx.doi.org/10.1177/1473095213501506

Dewulf, A. 2013. Contrasting frames in policy debates on climate change adaptation. Wiley Interdisciplinary Reviews: Climate Change 4(4):321-330. http://dx.doi.org/10.1002/wcc.227

Dewulf, A., B. Gray, L. Putnam, R. Lewicki, N. Aarts, R. Bouwen, and C. van Woerkum. 2009. Disentangling approaches to framing in conflict and negotiation research: a meta-paradigmatic perspective. Human Relations 62(2):155-193. http://dx.doi. org/10.1177/0018726708100356

Dewulf, A., S. Meijerink, and H. Runhaar. 2015. Editorial: the governance of adaptation to climate change as a multi-level, multi-sector and multi-actor challenge: a European comparative perspective. Journal of Water and Climate Change 6(1):1-8. http:// dx.doi.org/10.2166/wcc.2014.000

Dimov, D. 2007. Beyond the single-person, single-insight attribution in understanding entrepreneurial opportunities. Entrepreneurship Theory and Practice 31(5):713-731. http://dx. doi.org/10.1111/j.1540-6520.2007.00196.x

Doswald, N., and M. Osti. 2011. Ecosystem-based approaches to adaptation and mitigation - good practice examples and lessons learned in Europe. BfN-Skripten 306. Bundesamt für Naturschutz (BfN), Federal Agency for Nature Conservation, Bonn, Germany.

Eisenack, K., and R. Stecker. 2012. A framework for analyzing climate change adaptations as actions. Mitigation and Adaptation Strategies for Global Change 17(3):243-260. http://dx.doi. org/10.1007/s11027-011-9323-9

Entman, R. M. 1993. Framing: toward clarification of a fractured paradigm. Journal of Communication 43(4):51-58. http://dx.doi. org/10.1111/j.1460-2466.1993.tb01304.X

Feindt, P. H., and A. Netherwood. 2011. Making sense of climate change. Notes on interpretive policy analysis and discourse analysis in sustainability research. Pages 159-174 in P. Blyton and A. Franklin, editors. Researching sustainability: a guide to social science methods and practice. Earthscan, London, UK.

Fuentes Fuentes, M. d. M., M. R. Arroyo, A. M. Bojica, and V. F. Pérez. 2010. Prior knowledge and social networks in the exploitation of entrepreneurial opportunities. International Entrepreneurship and Management Journal 6(4):481-501. http:// dx.doi.org/10.1007/s11365-010-0136-1

Gray, B. 2002. Framing of environmental disputes. Pages 11-34 in R. Lewicki, B. Gray, and M. Elliott, editors. Making sense of intractable environmental conflicts: conflicts and cases. Island, Washington, D.C., USA.

Halme, M., and M. Korpela. 2014. Responsible innovation toward sustainable development in small and medium-sized enterprises: a resource perspective. Business Strategy and the Environment 23(8):547-566. http://dx.doi.org/10.1002/bse.1801

Huitema, D., W. N. Adger, F. Berkhout, E. Massey, D. Mazmanian, S. Munaretto, R. Plummer, and C. C. J. A. M. Termeer. 2016. The governance of adaptation: choices, reasons, and effects. Introduction to the Special Feature. Ecology and Society 21(3):37. http://dx.doi.org/10.5751/ES-08797-210337

Jones, H. P., D. G. Hole, and E. S. Zavaleta. 2012. Harnessing nature to help people adapt to climate change. Nature Climate Change 2(7):504-509. http://dx.doi.org/10.1038/nclimate1463

Lambooy, T., and Y. Levashova. 2011. Opportunities and challenges for private sector entrepreneurship and investment in biodiversity, ecosystem services and nature conservation. International Journal of Biodiversity Science, Ecosystem Services \& Management 7(4):301-318. http://dx.doi.org/10.1080/21513732.2011.629632

Lems, P., N. Aarts, and C. M. J. van Woerkum. 2013. When policy hits the ground. An empirical study of the communication practices of project managers of a water board in conversations for collaborative governance. Environmental Policy and Governance 23(4):234-246. http://dx.doi.org/10.1002/eet.1618

Massey, E., D. Huitema, H. Garrelts, K. Grecksch, H. Mees, T. Rayner, S. Storbjörk, C. Termeer, and M. Winges. 2015. Handling adaptation policy choices in Sweden, Germany, the UK and the Netherlands. Journal of Water and Climate Change 6(1):9-24. http://dx.doi.org/10.2166/wcc.2014.110

Mazmanian, D. A., J. Jurewitz, and H. T. Nelson. 2013. A governing framework for climate change adaptation in the built environment. Ecology and Society 18(4):56. http://dx.doi. org/10.5751/ES-05976-180456

Mees, H. L. P., P. P. J. Driessen, and H. A. C. Runhaar. 2012. Exploring the scope of public and private responsibilities for climate adaptation. Journal of Environmental Policy \& Planning 14(3):305-330. http://dx.doi.org/10.1080/1523908X.2012.707407

Milman, A., and K. Jagannathan. 2017. Conceptualization and implementation of ecosystems-based adaptation. Climatic Change 142(1-2):113-127. http://dx.doi.org/10.1007/s10584-017-1933-0

Ministerie van Infrastructuur en Milieu. 2015. Projectplan Achteroever Wieringermeer. Innoveren met water en 'agri' in de Wieringermeer. Ministerie van Infrastructuur en Milieu, 
Provincie Noord-Holland, Hoogheemraadschap Hollands Noorderkwartier, Gemeente Hollands Kroon, Wieringerwerf, The Netherlands.

Naumann, S., G. Anzaldua, P. Berry, S. Burch, M. Davis, M., A. Frelih-Larsen, H. Gerdes, and M. Sanders. 2011. Assessment of the potential of ecosystem-based approaches to climate change adaptation and mitigation in Europe. Final report to the European Commission, DG Environment. Ecologic Institute and Environmental Change Institute, Oxford University Centre for the Environment, Oxford, UK.

Ojea, E. 2015. Challenges for mainstreaming ecosystem-based adaptation into the international climate agenda. Current Opinion in Environmental Sustainability 14:41-48. https://doi.org/10.1016/ j.cosust.2015.03.006

Osterwalder, A., Y. Pigneur, and T. Clark. 2010. Business model generation: a handbook for visionaries, game changers, and challengers. Wiley, Hoboken, New Jersey, USA.

Patzelt, H., and D. A. Shepherd. 2011. Recognizing opportunities for sustainable development. Entrepreneurship Theory and Practice 35(4):631-652. http://dx.doi.org/10.1111/j.1540-6520.2010.00386. $\underline{\mathrm{X}}$

Penner, L. A., J. F. Dovidio, J. A. Piliavin, and D. A. Schroeder. 2005. Prosocial behavior: multilevel perspectives. Annual Review of Psychology 56(1):365-392. http://dx.doi.org/10.1146/annurev. psych.56.091103.070141

Secretariat of the Convention on Biological Diversity. 2009. Connecting biodiversity and climate change mitigation and adaptation: report of the Second Ad Hoc Technical Expert Group on Biodiversity and Climate Change. Technical Series No. 41. Secretariat of the Convention on Biological Diversity, Montreal, Quebec, Canada.

Shane, S. 2003. A general theory of entrepreneurship: the individualopportunity nexus. Edward Elgar, Cheltenham, UK. http://dx.doi. org/10.4337/9781781007990

Swart, R., A. G. J. Sedee, F. de Pater, H. Goosen, M. Pijnappels, and P. Vellinga. 2014. Climate-proofing spatial planning and water management projects: an analysis of 100 local and regional projects in the Netherlands. Journal of Environmental Policy \& Planning 16(1):55-74. http://dx.doi.org/10.1080/1523908X.2013.817947

Teisman, G. R., 2000. Models for research into decision-making processes: on phases, streams and decision-making rounds. Public Administration 78(4):937-956. http://dx.doi.org/10.1111/1467-9299.00238

Tompkins, E. L., and H. Eakin. 2012. Managing private and public adaptation to climate change. Global Environmental Change 22(1):3-11. http://dx.doi.org/10.1016/j.gloenvcha.2011.09.010

Van Huijstee, M. M., M. Francken, and P. Leroy. 2007. Partnerships for sustainable development: a review of current literature. Environmental Sciences 4(2):75-89. http://dx.doi. org/10.1080/15693430701526336

van Lieshout, M., A. Dewulf, N. Aarts, and C. Termeer. 2011. Do scale frames matter? Scale frame mismatches in the decision making process of a "mega farm" in a small Dutch village. Ecology and Society 16(1):38. http://dx.doi.org/10.5751/ES-04012-160138
Veerman, C. 2008. Working together with water: a living land builds for its future. Secretariat Delta Committee, The Hague, The Netherlands.

Vink, M. J., D. Boezeman, A. Dewulf, and C. J. A. M. Termeer. 2013. Changing climate, changing frames: Dutch water policy frame developments in the context of a rise and fall of attention to climate change. Environmental Science \& Policy 30:90-101. http://dx.doi.org/10.1016/j.envsci.2012.10.010

Yin, R. K. 2003. Case study research: design and methods. Sage, Thousand Oaks, California, USA. 